\title{
Editorial
}

\section{Antropoceno - Tecnógeno: o Brasil avança nas pesquisas}

Quando o editor me convidou para realizar um volume temático da Revista sobre o Tecnógeno não foi difícil aceitar o desafio, pois já havíamos realizado o Primeiro Encontro Brasileiro do Tecnógeno em 2005, durante o X Congresso da ABEQUA, em Guarapari. Neste mesmo ano, o livro da ABEQUA - Quaternário do Brasil - estava sendo lançado, contemplando um capítulo sobre o tema - Tecnógeno: Registros da Ação Geológica do Homem. Além disso, nos incentivou, também, o fato de que a comunidade científica está discutindo a definição de uma nova época - o Antropoceno, no âmbito de um Grupo de Trabalho da International Commission on Stratigraphy (ICS) da International Union of Geological Science (IUGS). Temos certeza que volume contribuirá para os debates do grupo, que concluirá seus trabalhos em 2016.

A proposta do Tecnógeno é de Ter-Stepanian, feita em 1989, no âmbito da IAEG International Association of Engineering Geology, considerando o Holoceno como o começo do Tecnógeno, há cerca de 10.000 anos antes do presente, tendo como referência a Revolução Agrícola, a primeira revolução tecnológica, a ser concluído quando todas as paisagens naturais tiverem sido alteradas pela Humanidade. A proposta do Antropoceno é de Stoermer e Crutzen, feita em 2000, considerando seu início na Revolução Industrial, na Europa em torno do ano de 1800, considerando que as transformações antrópicas atingiram a escala planetária. Embora ainda não tenha sido formalmente definido como unidade da escala de tempo geológico, o termo Antropoceno já vem sendo largamente aplicado no mundo científico e foi adotado definitivamente pela mídia.

Neste semestre de 2014, quando a ABEQUA comemora os seus 30 anos, a publicação do volume especial “Antropoceno - Tecnógeno" é como um presente para todos nós associados para enriquecermos nosso debate sobre as transformações ambientais do passado, do presente e do futuro e, assim, aprofundarmos nossas reflexões sobre nosso papel como cientistas do Quaternário, sobre a vida da nossa Terra.

Permanecerei, por todo o Quaternário, grato ao Rodolfo J. Angulo que proporcionou esta realização; a todos os autores e revisores, que contribuíram de forma inestimável; a Maria Cristina de Souza, pela ajuda permanente aos meus pedidos de socorro, solucionando todos os problemas, e a Claudia Ortiz pelo esforço de editoração. Finalmente, registro meus profundos agradecimentos à minha esposa Adriana Oliveira que, entusiasmada por sua pesquisa de mestrado sobre depósitos tecnogênicos, me deu o apoio decisivo para que eu pudesse cumprir mais uma missão nossa, de forma consistente do início ao fim.

Prof. Dr. Antonio Manoel dos Santos Oliveira Chefe do Laboratório de Geoprocessamento Mestrado em Análise Geoambiental - MAG Universidade Guarulhos - UnG 